\title{
Examining the Decision to Opt In versus Opt Out of Section 107 of the JOBS Act of 2012: Determinants and Consequences
}

\author{
Jason Bergner ${ }^{1}$, Marcus R. Brooks ${ }^{2} \&$ Binod Guragai $^{3}$ \\ ${ }^{1}$ Gordon Ford College of Business, Western Kentucky University, Bowling Green, Kentucky, USA \\ ${ }^{2}$ College of Business, The University of Nevada, Reno, Nevada, USA \\ ${ }^{3}$ McCoy College of Business Administration, Texas State University, San Marcos, Texas, USA \\ Correspondence: Marcus R. Brooks, College of Business, The University of Nevada, Reno, Nevada 89557, USA. Tel: \\ 1-775-784-6699. E-mail: marcusbrooks@unr.edu
}

Received: February 21, 2019

Accepted: March 28, 2019

Online Published: March 30, 2019

doi:10.5430/afr.v8n2p108

URL: https://doi.org/10.5430/afr.v8n2p108

\begin{abstract}
The Jumpstart Our Business Startups Act of 2012 (hereafter, JOBS Act) creates a new category of firms, referred to as "Emerging Growth Companies" (hereafter, EGCs). Section 107 of the JOBS Act, titled "Opt-In Right for EGCs," gives EGCs the choice to take advantage of an extended transition period for complying with new or revised accounting standards. In other words, an EGC can choose to delay the adoption of new or revised accounting standards until those standards would otherwise apply to private companies. Using a logistic regression approach with hand-collected data, we examine the underlying firm characteristics associated with EGCs' choice of opting in or out of the accounting standards exemption, as provided by Section 107 of the JOBS Act. Using additional ordinary least square regression analyses, we further examine whether the choice of opting in or out is associated with earnings management and financial statement restatement behavior. Our results suggest that EGC firms designated as "smaller reporting companies" are more likely to choose to delay the adoption of a new or revised accounting standard (i.e., opt in). Our findings also show that EGCs that employ Big 4 auditors are more likely to opt out. We further find that EGCs that choose to opt out are less likely to engage in earnings management behavior, proxied by the absolute value of abnormal accruals, and are less likely to restate their financial statements. Taken together, our findings suggest that EGCs that choose to opt out of Section 107 produce higher quality financial statements.
\end{abstract}

Keywords: JOBS Act, accounting standards, earnings management, earnings quality, financial statement restatements

\section{Introduction}

The influence of accounting standards on financial reporting quality has long been a topic of interest to standard-setters, regulators, academics, and investors, and the influence that financial reporting quality has on capital markets and business and investment decisions has been a mainstay of accounting research for decades. The Jumpstart Our Business Startups Act of 2012 (hereafter, JOBS Act) creates a new category of firms, referred to as "Emerging Growth Companies" (hereafter, EGCs). Section 107 of the JOBS Act, titled "Opt-In Right for EGCs," gives EGCs the choice to take advantage of an extended transition period for complying with new or revised accounting standards. (Note 1) In other words, an EGC can choose to delay the adoption of new or revised accounting standards until these standards would otherwise apply to private companies should the EGC choose to opt in. (Note 2) If, however, an EGC chooses to opt out of the accounting standards exemption, the firm must comply with new or revised accounting standards as if it were not an EGC. Any decision to forego the extended transition period for complying with the new or revised accounting standards is irrevocable. By using this unique setting in which firms are allowed to choose between alternative accounting standards, we strive to provide insight into the determinants and consequences associated with regulatory choice and how this choice influences financial reporting quality and restatement behavior.

In this study, we first seek to answer the question, "What type of firms choose to opt in versus opt out of Section 107 of the Jobs Act?" Because this decision has a direct influence on compliance with new or revised accounting standards, we then attempt to answer the question, "Does the decision to opt in or opt out of Section 107 of the Jobs 
Act influence firm financial reporting quality and restatement behavior?" To answer these questions, we first examine the underlying firm characteristics associated with an EGC's choice of opting in versus opting out of Section 107. Then, to understand the significance associated with this decision, we examine whether earnings quality and financial statement restatement behavior is influenced by the decision to adopt (or delay) new or revised accounting standards. Examination of this decision can help to provide insight into the costs and benefits associated with the issuance and adoption of new or revised accounting standards.

Our initial sample includes EGC firms that filed initial public offerings (hereafter, IPOs) for the first time during the period of April 15, 2012, to December 31, 2015. We hand collected data from Securities and Exchange Commission (hereafter, SEC) filings on EGCs' choice of opting in or out of compliance with new or revised accounting standards. We then used Compustat and Audit Analytics to gather financial and descriptive data pertinent to our primary analyses. Our logistic regression results suggest that EGC firms that are also considered "smaller reporting companies" (hereafter, SRCs) are more likely to choose to delay the adoption of new or revised accounting standards (i.e., opt in). (Note 3) In addition, our findings also show that EGCs that employ Big 4 auditors are more likely to opt out. We further find that EGCs that choose to opt out are less likely to engage in earnings management behavior, as proxied by the absolute value of abnormal accruals, and are less likely to restate their financial statements. Taken together, our findings suggest that EGCs that chose to opt out of Section 107 of the JOBS Act produce higher quality financial statements.

Our study complements prior research and contributes to the accounting literature in at least two ways. First, we examine various underlying firm characteristics that may be determinants of whether EGCs choose to delay the adoption of new or revised accounting standards (i.e., opt in vs. opt out). Because EGCs may incur significant direct and indirect costs when adopting new or revised accounting standards, understanding the determinants that influence the choice to opt in or out may be important for regulators, firms, and investors. Our findings may be helpful in initiating a conversation about designing a phase-in strategy or implementation guidelines for firms that are unable to meet the challenges associated with the issuance of new or revised accounting standards. Failure to address these issues may result in a lack of financial statement comparability, which could have an adverse effect on financial statement reliability and access to capital for firms that have significant financial constraints.

Second, we attempt to understand how the decision to delay or adopt new or revised accounting standards affects financial reporting quality. Section 107 of the JOBS Act provides researchers with a natural experimental setting to understand how the choice of adopting new or revised accounting standards affects financial reporting quality. The evidence from our findings suggests that EGCs that choose to comply with new or revised accounting standards (i.e., opt out) have higher reporting quality, as proxied by the absolute value of abnormal accruals and lower incidences of financial statement restatements. Such evidence should be of interest to regulators, investors, and analysts. Our findings also shed light on the differences in reporting quality among firms within the same reporting classification. Without understanding the differences in reporting quality associated with these firms, users of their financial statements may make suboptimal analytical, investing, and capital-budgeting decisions.

The remainder of the paper is organized as follows. Section 2 provides the background to the JOBS Act and the basis for our hypotheses. Section 3 presents the research design, sample selection procedure, and methodology. Section 4 includes the findings, Section 5 provides a discussion of the results, and Section 6 offers a summary and concluding remarks.

\section{Background and Hypothesis Development}

\subsection{The JOBS Act of 2012}

The JOBS Act was enacted by the US Congress in April 2012 and retroactively included businesses that offered IPOs after December 8, 2011. (Note 4) The JOBS Act created a new category for firms to choose as a classification when filing financial statements, registration statements, and other required documents with the SEC. (Note 5) Firms eligible under the JOBS Act can elect to be classified as "Emerging Growth Companies." The purpose of the EGC designation under the JOBS Act was to relax the reporting requirements for firms that initially offer stock on US equity markets (IPOs) or those that had recently done so. The JOBS Act was, at least partially, in response to a dramatic decline in the number of IPOs that were being offered in the United States (Jensen, Marshall, \& Jahera, 2012). The relaxation of requirements under the JOBS Act was intended to increase access to the capital markets for new and emerging growth companies, which would, in turn, spur job creation and economic growth (HR 3606). (Note 6) 
Under the JOBS Act, eligible firms could elect, but are not obliged to take, the EGC designation. If elected, the company maintains its EGC designation until meeting one of the following criteria:

- Reaches the last day of its fiscal year, following the fifth anniversary of its IPO

- Completes a fiscal year in which it exceeds annual gross revenues (adjusted for inflation) of \$1B

- Issues more than \$1B in non-convertible debt during the previous three-year period

- Becomes a "large accelerated filer" (Note 7)

The JOBS Act specifically reduces reporting requirements for an EGC for as long as the firm is eligible for categorization as an EGC. An EGC may elect to use any of the exemptions afforded it (i.e., cafeteria-style selection), but it may not selectively choose specific accounting standards to avoid adopting. The accounting standards adoption is an "all or none" selection. Figure 1 provides a description of the IPO reliefs that the JOBS Act provides for reporting requirements.

\section{IPO Relief}

Delayed acquisition of new accounting standards

Reduced financial statement and MD\&A disclosure

Exemption from new PCAOB audit requirements

Reduced executive compensation disclosure

Expansion of permitted investor communications

Confidential submission of registration statements

Relaxation of research analyst restrictions

\section{Description}

EGCs are not subject to any adopted or revised accounting standards for public companies after April 5, 2012. This election must be must for all standards or none (cannot be selectively applied), and it is non-revocable.

In IPO statements, EGCs are required only to present two years (instead of three) of audited financial statements plus unaudited interim statements. The EGC need not present unaudited selected financial data in its registration statements, and MD\&A needs to cover only the fiscal periods required for financial statements.

EGCs are not required to implement new auditing standards unless the SEC determines that the adoption of these standards is necessary and in the public's interest.

EGCs are allowed to present the "scaled" executive compensation disclosures previously allowed only to smaller reporting companies.

EGCs have more freedom to communicate with potential "qualified institutional buyers" and "accredited investors" (as defined by Regulation D) both before and after the filing of the registration statement, including during the "quiet period."

EGCs are allowed to submit a confidential S-1 to the SEC for review instead of publicly. Confidential submissions are exempt from Freedom of Information Act requests.

Research analysts are permitted to attend meetings with company management and other broker-dealer personnel. Analysts are also able to attend investor meetings arranged by investment bankers. They may also publish research reports about the company both prior to and after the filing of the registration statement, including during any blackout period.

Figure 1. Emerging growth company IPO relief

In addition, there are post-IPO benefits afforded to EGCs through the JOBS Act. EGCs are exempt from section 404(b) of the Sarbanes-Oxley Act of 2002 (hereafter, SOX), which requires an independent registered public accounting firm audit and report on the effectiveness of a company's internal control over financial reporting. EGCs also are exempt from the provisions of the Dodd-Frank Act of 2010 that require companies to seek shareholder approval of an advisory vote on executive compensation arrangements, including golden parachute compensation. Finally, EGCs are exempt from Dodd-Frank Act requirements that mandate disclosures about the relationship between executive compensation and financial performance and the ratio between CEO compensation and median employee compensation.

Our review of 1,044 filings by EGCs show that most EGCs choose to take reduced reporting requirements offered by the JOBS Act, with the exception of the adoption of new accounting standards. We find that there is wide variation in the number of firms that choose to delay adoption of new accounting standards versus those that choose to comply 
with any new accounting standards. This setting allows us to understand firms that subject themselves to the new accounting standards even though these firms are allowed to delay the adoption of those standards.

\subsection{The JOBS Act, IPOs, and EGCs}

Prior literature concerning the JOBS Act has focused mainly on the various effects that the JOBS Act has had on the IPO market. Ritter and Welch (2002) provide a comprehensive overview of IPO research and find that firms are initially underpriced. This is likely due to the information asymmetry inherent in new firms, as investors do not have as complete a picture of an IPO as they would about a long-established firm. Barth, Landsman, and Taylor (2017) find an increase in information uncertainty around the IPO event, reporting an average underpricing that ranges from $6.3 \%$ to $12.9 \%$ of IPO proceeds for EGC firms. Chaplinsky, Hanley, and Moon (2017), however, find no evidence of a direct cost reduction for EGC firms in the IPO process and, instead, document an $11 \%$ increase in indirect costs, as measured by underpriced IPOs. Dambra, Field, and Gustafson (2015) show that the IPO volume increased after the JOBS Act and that this increase is concentrated mainly in firms with high proprietary costs of disclosure. That is, certain industries are more likely to have higher disclosure costs. Firms in these industries are more likely to elect EGC status to avoid these higher costs.

Westfall and Omer (2018) extend this work into the EGC domain and find that EGCs' lowered disclosure requirements increase this information asymmetry. As a result, investors view EGCs as riskier investments. Westfall and Omer also find evidence that audit fees increased for firms that applied provisions of the JOBS Act. Specifically, although auditors work harder (increased fees) to mitigate this risk, they are unable to completely do so. In other research related to ECG disclosures, Gipper (2016) finds that reduced disclosure requirements related to executive compensation information are associated with a significant reduction in CEO pay. Dambra, Field, Gustafson, and Pisciotta (2016) also find that changes in affiliated analysts' behavior increase post-IPO trading volumes, thereby affecting analysts' compensation packages and brokerage firm revenues.

Although prior research on the JOBS Act focuses primarily on the influence that the JOBS Act has had on the IPO market as well as the JOBS Act's association with audit markets, compensation levels, and disclosure requirements, we seek to focus on a unique election allowance within Section 107 of the JOBS Act. Although Chaplinsky et al. (2017) find a greater underpricing for EGCs, this significant finding is for only larger EGCs. This is an important distinction, as it hints at underlying differences between small and large EGCs. We further investigate these underlying differences in EGCs to determine whether certain characteristics play a role in the decision to opt in versus opt out of Section 107 and the influence that election has on earnings quality and restatement behavior.

\subsection{Section 107 Election and EGC Firm Size}

Because Section 107 of the JOBS Act gives EGCs the choice of adopting or delaying new or revised accounting standards, we can examine whether certain firm characteristics are influential in the decision to opt in versus opt out. The implementation and adoption of new accounting standards requires significant direct and indirect costs on firms, causing them to incur significant expenditures, both financial and non-financial. Loyeung and Matolcsy (2016), in their examination of the costs of implementing International Financial Reporting Standards (IFRS) in Australia, find that the application of more complex accounting standards resulted in the greatest frequency and size of implementation errors. Further, the uncertainty associated with new or revised accounting standards that may be adopted in the future could lead to uncertainty about potential costs associated with implementation.

Consistent with the findings of Chaplinsky et al. (2017), we believe that a determining firm characteristic in the decision to take advantage of the Section 107 provision is the size of the EGC firm. EGC firms that are larger in size are likely able to afford the costs associated with compliance with new or revised accounting standards more easily than are smaller EGC firms due to the firm resources that they possess. Smaller EGC firms may choose to avoid these potential costs, affording them both short-term certainty and the benefit of freeing up potential dollars for growing the company. As such, we expect that smaller EGC firms will be more likely to use the opt in provision provided by Section 107 of the JOBS Act and delay adoption of any new or revised accounting standards. Following this line of reasoning, we propose:

H1a: Smaller firms are more likely to take advantage of the JOBS Act provision in Section 107 and opt in, thereby delaying compliance with new or revised accounting standards.

\subsection{Section 107 Election and EGC Firm Auditor}

We believe that another influential factor that affects the choice of complying with new or revised accounting standards relates to whether EGC firms have Big 4 or non-Big 4 auditors. Consistent with the assertions of prior research that documents that Big 4 offices provide superior quality (Francis \& Krishnan, 1999; Kim, Chung, \& Firth, 
2003), we contend that Big 4 auditors have greater access to resources and tools concerned with implementing new accounting standards. Further, Big 4 auditors, in an attempt to avoid reputation losses that stems from audit failure, are likely more selective in choosing clients who would want to comply with new or revised accounting standards to decrease risks.

Teoh and Wong (1993) and Balsam, Krishnan, and Yang (2003) also suggest that Big 4 clients have more informative and higher quality earnings. Because Big 4 auditors have the resources and experience in dealing with SEC reporting requirements, they should be able to effectively provide guidance and assist their clients in complying with new or revised accounting standards. As a result, EGC firms with Big 4 auditors would likely have more confidence in their ability to successfully adopt future accounting standards. We hypothesize that EGC firms with Big 4 auditors will be more likely to forego the JOBS Act provision to delay the adoption of new or revised accounting standards and choose to opt out, thereby complying with all accounting standards. As such, we propose:

H1b: Firms with Big 4 auditors are more likely to choose to comply with new accounting standards and forego the related benefit provided through Section 107 of the JOBS Act.

\subsection{EGC Section 107 Election and Financial Statement Quality and Restatement Behavior}

Extant research shows that smaller firms and those audited by non-Big 4 auditors are associated with reduced financial reporting quality and less informative earnings (Balsam et al., 2003; Teoh \&Wong, 1993). In addition, Westfall and Omer (2018) contend that EGCs' perceived business risk is likely higher because the reduced information increases the risk of surprise (e.g., restatement) from information not included in the registration statement. Providing support for their contention, Guasch (2017) documents a significant difference in the information content of earnings for EGCs relative to non-EGCs following the JOBS Act. Zimmerman (2015) finds that firms with greater board independence and audit committee expertise are more likely to forego the exemptions afforded by the JOBS Act. Because firms with greater board independence and audit committee expertise are more likely to have higher financial statement quality (e.g., Bilal, Chen, \& Komal 2018), Zimmerman (2015) hints at a relationship between EGCs' election choices and financial statement quality.

Following the results of previous studies, we expect that the financial information provided by those EGCs that choose to opt in and delay the adoption of new or revised accounting standards will be of lower quality and be less informative than that of EGCs that chose to opt out and comply with new or revised accounting standards. We test this contention by using two measures of financial reporting quality: accrual earnings management and financial statement restatements. We hypothesize that firms that opt in (i.e., take advantage of the JOBS Act Section 107 provision) will have lower quality financials, be more likely to engage in accrual earnings management, and have a higher incidence of financial statement restatements as compared to those EGCs that chose to opt out. As such, we propose:

H2a: Firms that elect to take advantage of accounting rules exemptions are more likely to engage in accrual earnings management.

H2b: Firms that elect to take advantage of accounting rules exemptions are more likely to restate their financial statements.

\section{Research Design}

\subsection{Methodology}

Hypotheses H1a and H1b concern whether firm size and choice of auditor, respectively, are associated with the choice of opting in or opting out of the accounting standard exemption provided by Section 107 of the JOBS Act. An EGC's designation as an SRC proxies for firm size whereas use of one of the Big 4 auditors by EGC proxies for auditor choice. To test these hypotheses, we employ a logistic regression as follows:

$$
\begin{aligned}
& \operatorname{Pr}\left(\text { Optout }_{i}=1 \mid \boldsymbol{x}\right)=F\left(\beta_{0}+\beta_{1} \text { Sml_Rpt }_{i}+\beta_{2} \text { Big }_{i}+\beta_{3} \text { Lev }_{i}+\beta_{4} \text { Loss }_{i}+\beta_{5} \text { Cf } f_{i}+\beta_{6} \text { Growth }_{i}+\text { Industry }_{1}\right. \\
& \text { dummies }_{i}+\text { Year dummies } \text { d }_{i}
\end{aligned}
$$

where $\mathrm{F}=1 /\left[1+\exp ^{(-\mathbf{x B})}\right]$.

In our analysis, the variable Optout is an indicator variable equal to 1 if an EGC firm chooses to opt out of the accounting rules exemption, and 0 otherwise. Sml_Rpt is an indicator variable equal to 1 if the EGC is designated as a smaller reporting company in SEC filings, and 0 otherwise. We expect a negative coefficient on Sml_Rpt, which would suggest that SRCs (i.e., small-sized firms) are less likely to opt out of the accounting rules exemption (i.e., more likely to choose to forego adopting new standards). Big4 is an indicator variable equal to 1 if the EGC employs one of the Big 4 auditors, and 0 otherwise. We expect a positive coefficient on Big4, which would support our 
conjecture that firms with Big 4 auditors are more likely to be subjected to the adoption of new or revised accounting standards.

Based on the empirical evidence from prior literature, we include a number of control variables, including leverage, loss indicator, cash flow from operations, and growth. Lev represents the EGC firm leverage and is calculated as total debt divided by the book value of equity. Loss is an indicator variable equal to 1 if the EGC reports a loss from operations at the end of the fiscal year, and 0 otherwise. $C f$ represents the firm's cash flow from operations and is scaled by total assets at year end. Growth represents the firm's market value of equity divided by book value of equity at year end. In equation (1), $\beta_{1}$ and $\beta_{2}$ are the variables of interest to test $\mathrm{H} 1 \mathrm{a}$ and $\mathrm{H} 1 \mathrm{~b}$, respectively. All variables used in our analysis are defined in Appendix A.

Hypothesis H2a concerns whether firms that opt out of the accounting standards exemption are less likely to engage in accruals-based earnings management. We employ the modified Jones model, adjusted for return on assets (hereafter, ROA), to estimate abnormal accruals and utilize the absolute value of abnormal accruals as a proxy for accruals-based earnings management. The following ordinary least square (hereafter, OLS) regression model is used to test $\mathrm{H} 2 \mathrm{a}$ :

$$
\begin{aligned}
& \text { AbsDa } a_{i}=\beta_{0}+\beta_{1} \text { Optout }_{i}+\beta_{2} \text { Sml_Rpt }_{i}+\beta_{3} \text { Big }_{i}+\beta_{4} \text { Lev }_{i}+\beta_{5} \text { Loss }_{i}+\beta_{6} \text { Cf }_{i}+\beta_{7} \text { Growth }_{i}+\text { Industry } \\
& \text { dummies }_{i}+\text { Year dummies }_{i}+e_{i}
\end{aligned}
$$

where $A b s D A$ represents the absolute value of abnormal accruals, calculated following the modified Jones model, adjusted for financial performance, following Kothari, Leone, and Wasley (2005).

In equation (2), $\beta_{l}$ is the variable of interest to test hypothesis H2a. We include an SRC indicator, auditor indicator, leverage, loss indicator, cash from operations, and growth to control for other potentially explanatory variables.

Hypothesis $\mathrm{H} 2 \mathrm{~b}$ concerns whether firms that opt out of the accounting standards exemptions are less likely to restate their financial statements. To test $\mathrm{H} 2 \mathrm{~b}$, we employ the following logistic regression model in which the dependent variable, Restatement, is an indicator variable equal to 1 if the firm restates its financial statements, and 0 otherwise:

$$
\begin{aligned}
& \operatorname{Pr}\left(\text { Restatement }_{i}=1 \mid \boldsymbol{x}\right)=F\left(\beta_{0}+\beta_{1} \text { Optout }_{i}+\beta_{2} \text { Sml_Rpt }_{i}+\beta_{3} \text { Big }_{i}+\beta_{4} \text { Lev }_{i}+\beta_{5} \text { Loss }_{i}+\beta_{6} \text { Cf } f_{i}+\beta_{7}\right. \\
& \text { Growth } \left._{i}+\text { Industry dummies }_{i}+\text { Year dummies }_{i}\right)
\end{aligned}
$$

where $\mathrm{F}=1 /\left[1+\exp ^{(-\mathbf{x B})}\right]$.

In equation (3), $\beta_{1}$ is the variable of interest to test hypothesis $\mathrm{H} 2 \mathrm{~b}$. We include an SRC indicator, auditor indicator, leverage, loss indicator, cash from operations, and growth to control for other potentially explanatory variables. As an alternative, we also estimate equation (3), using OLS regression.

\subsection{Sample Selection and Data}

Table 1 presents the sample selection procedure. We start by downloading firms designated as EGCs from Audit Analytics for the period of April 15, 2012 to December 31, 2015. We found 1,044 unique US IPO firms with an EGC designation during the sample period. We then hand collected data from SEC filings (S-1, 10-Q, 10-K, 10-12G, and/or other applicable forms) and documented whether an EGC elected to opt in or out of the accounting rules exemption provided by Section 107 of the JOBS Act. It is important to note that, once an EGC elects to opt out of the exemption, such election becomes irrevocable. We could not clearly locate the option preference for $216 \mathrm{EGC}$ firms. For the remaining sample, we then merged our data to collect financial information from Compustat, using Central Index Keys. During this process, we could not find the required financial information for another 404 EGC firms. As a result, our final sample is comprised of 424 unique EGC firms.

Table 1. Sample Selection

\begin{tabular}{ll}
\hline Data Source & $n$ \\
\hline US firms with IPO filing as EGC during April 15, 2012-December 31, 2015 & 1,044 \\
Less: firms without clear information to hand collect Optout variable & $(216)$ \\
Less: firms without required financial information from Compustat for regression analyses & $\underline{(404)}$ \\
Final sample of unique firms for testing H1a and H1b & 424 \\
Final sample of firm-years for testing H2a & 1,426 \\
Final sample of firm-years for testing H2b & 1,436
\end{tabular}


For the testing of $\mathrm{H} 2 \mathrm{a}$, we first estimate abnormal accruals, following the modified Jones model, and include additional firm-years of the 424 firms to increase the power of the tests and to reduce any bias that results from accrual reversal. Our final sample for H2a includes 1,426 firm-years from 2012 to 2017. Finally, to test H2b, we collect restatement data from Audit Analytics, and our final sample includes 1,436 firm years.

\section{Results}

\subsection{Descriptive Statistics}

Table 2 presents the descriptive statistics of the sample. Of the 424 EGCs with the available requisite information, approximately $66 \%$ chose to opt out of the accounting rules exemption provided by Section 107 of the JOBS Act. In addition to being classified as an EGC, approximately $41 \%$ of the sample was designated as an SRC. Approximately $42 \%$ of the EGC firms employed one of the Big 4 auditors, and approximately $56 \%$ of the EGC firms reported a loss during the sample period. The descriptive statistics show that the firms included in our sample are small, having negative cash flows from operations, likely resulting in losses. The descriptive statistics may help to validate our theory development with regard to $\mathrm{H} 1$, as those firms that are small have negative operating cash flows and have reported a loss are less likely to adopt new or revised accounting standards that could result in increased current and future cost to the firm.

Table 2. Descriptive Statistics

\begin{tabular}{llcccc}
\hline Variable & $N$ & Mean & Median & Q1 & Q3 \\
\hline Optout & 424 & 0.658 & 1.000 & 0.000 & 1.000 \\
Sml_Rpt & 424 & 0.410 & 0.000 & 0.000 & 1.000 \\
Big4 & 424 & 0.415 & 0.000 & 0.000 & 1.000 \\
Lev & 424 & 0.416 & 0.000 & -0.070 & 0.000 \\
Loss & 424 & 0.561 & 1.000 & 0.000 & 1.000 \\
Cf & 424 & -1.248 & 0.000 & -0.608 & 0.000 \\
Growth & 424 & -34.527 & 0.000 & 0.000 & 0.000 \\
AbsDa & 1426 & 0.558 & 0.300 & 0.128 & 0.670 \\
Restatement & 1436 & 0.068 & 0.000 & 0.000 & 0.000 \\
\hline
\end{tabular}

This table reports the descriptive statistics for variables used in the regression analysis.

\subsection{Correlation Analysis}

Table 3 displays the Pearson and Spearman correlation coefficients among the variables used in testing H1a and H1b. These univariate statistics are consistent with Hypotheses $\mathrm{H} 1 \mathrm{a}$ and H1b, as Optout is negatively associated with Sml_Rpt and positively associated with Big4. Conversely stated, firms that are considered an SRC are less likely to have a Big 4 auditor, more likely to have reported a loss, and more likely to have negative cash flows from operations. All of these factors may play a vital role in these firms' decision to take advantage and to opt in, thereby enjoying a delayed transition to adopt new or revised accounting standards. 
Table 3. Correlation Analysis

\begin{tabular}{llllllll}
\hline Variable & 1 & 2 & 3 & 4 & 5 & 6 & 7 \\
\hline 1. Optout & & $\mathbf{- 0 . 4 5 0}$ & $\mathbf{0 . 3 9 5}$ & 0.016 & $\mathbf{0 . 1 3 4}$ & -0.006 & -0.001 \\
2. Sml_Rpt & $\mathbf{< . 0 0 0 1}$ & $<.0001$ & 0.737 & $\mathbf{0 . 0 0 6}$ & 0.906 & 0.981 \\
& $\mathbf{- 0 . 4 5 0}$ & & $\mathbf{- 0 . 5 7 6}$ & -0.068 & $\mathbf{- 0 . 1 0 3}$ & $\mathbf{- 0 . 0 8 9}$ & $\mathbf{- 0 . 0 8 1}$ \\
3. Big4 & $<.0001$ & & $<.0001$ & 0.162 & $\mathbf{0 . 0 3 4}$ & $\mathbf{0 . 0 6 8}$ & $\mathbf{0 . 0 9 7}$ \\
& $\mathbf{0 . 3 9 5}$ & $\mathbf{- 0 . 5 7 6}$ & & -0.026 & $\mathbf{0 . 3 5 9}$ & 0.036 & 0.056 \\
4. Lev & $<.0001$ & $<.0001$ & & 0.598 & $<.0001$ & 0.454 & 0.247 \\
& $\mathbf{- 0 . 1 2 4}$ & 0.059 & $\mathbf{- 0 . 1 1 5}$ & & $\mathbf{- 0 . 0 8 4}$ & 0.019 & 0.035 \\
5. Loss & $\mathbf{0 . 0 1 1}$ & 0.229 & $\mathbf{0 . 0 1 8}$ & & $\mathbf{0 . 0 8 6}$ & 0.695 & 0.475 \\
& $\mathbf{0 . 1 3 4}$ & $\mathbf{- 0 . 1 0 3}$ & $\mathbf{0 . 3 5 9}$ & $\mathbf{- 0 . 3 3 1}$ & & $\mathbf{- 0 . 1 3 4}$ & -0.067 \\
6. Cf & $\mathbf{0 . 0 0 6}$ & $\mathbf{0 . 0 3 4}$ & $<.0001$ & $<.0001$ & & $\mathbf{0 . 0 0 6}$ & 0.166 \\
& 0.013 & $\mathbf{- 0 . 1 0 6}$ & -0.076 & $\mathbf{0 . 3 8 3}$ & $\mathbf{- 0 . 6 6 7}$ & & $\mathbf{0 . 6 2 6}$ \\
7. Growth & 0.795 & $\mathbf{0 . 0 2 9}$ & 0.116 & $<.0001$ & $<.0001$ & & $<.0001$ \\
& $\mathbf{- 0 . 1 5 7}$ & 0.030 & -0.022 & $\mathbf{0 . 4 0 6}$ & 0.002 & 0.056 & \\
\hline
\end{tabular}

Table 3 presents the Pearson and Spearman correlations of all variables used in the regression analysis. Pearson correlations appear below the diagonal, and Spearman correlations appear above the diagonal. Correlations that are significant at the 10 percent level or better are indicated in bold. All variables are defined in Appendix A.

\subsection{EGC Decision to Opt In versus Opt Out}

Table 4 shows the results of the tests of H1a and H1b. We present logistic as well as OLS regression results as alternative testing. The dependent variable in both the logistic and OLS regression is Optout, which is an indicator variable equal to 1 if the firm opts out of the accounting rules exemption, and 0 otherwise. The results of the logistic regression suggest that firms are significantly more likely to opt in and take advantage of the delayed transition period if they designate themselves as an SRC. We find that firms are more likely to opt out if they have employed one of the Big 4 auditors. Untabulated odds ratio estimates from logistic regression analysis suggest that EGC firms that are classified as an SRC are 19\% less likely to opt out of accounting rules exemption as compared to those that are not classified as an SRC. Similarly, EGC firms that use Big 4 auditors are $75 \%$ more likely to opt out of accounting rules exemption as compared to those that use non-Big 4 auditors. These results are economically significant and provide support for H1a and H1b. 
Table 4. Determinants of Opting Out of Accounting Rules Exemption

\begin{tabular}{|c|c|c|c|c|c|c|}
\hline \multirow[b]{2}{*}{ Variable } & \multicolumn{3}{|c|}{ Logistic Regression Analysis } & \multicolumn{3}{|c|}{ OLS Regression Analysis } \\
\hline & Estimate & $t$-value & $p$-value & Estimate & $t$-value & $p$-value \\
\hline Intercept & 0.9060 & 3.65 & 0.000 & 0.4015 & 3.22 & 0.001 \\
\hline Sml_Rpt & -1.4809 & -5.42 & $<.0001$ & -0.2862 & -4.71 & $<.0001$ \\
\hline Big4 & 1.1524 & 3.47 & 0.001 & 0.2072 & 3.62 & 0.000 \\
\hline Lev & -0.0001 & -0.01 & 0.993 & 0.0017 & 0.79 & 0.431 \\
\hline Loss & 0.1408 & 0.55 & 0.583 & -0.0067 & -0.14 & 0.887 \\
\hline$C f$ & -0.0061 & -0.49 & 0.624 & -0.0028 & -0.98 & 0.329 \\
\hline Growth & -0.0001 & -0.28 & 0.777 & 0.0000 & -0.13 & 0.896 \\
\hline Industry effects & Yes & & & Yes & & \\
\hline Year effects & Yes & & & Yes & & \\
\hline$N$ & 424 & & & 424 & & \\
\hline Pseudo $R^{2}$ & 0.41 & & & & & \\
\hline Adj. $R^{2}$ & & & & 0.24 & & \\
\hline
\end{tabular}

Table 4 presents the coefficient estimates from Logistic and OLS regression of Opting Out of Section 107 of the JOBS Act (i.e., firms choosing to forego the election to delay the adoption of new or revised accounting standards) on various firm characteristics. Amounts shown in bold are significant at least at the 5 percent level. Fixed effects are included for year and industry. All variables are defined in Appendix A.

\subsection{EGC Section 107 Decision to Opt Out and Earnings Management}

Table 5 presents the results of testing H2a, which states that EGCs that choose to opt out of the accounting standards exemption are less likely to engage in accrual earnings management. The dependent variable, $A b s D a$, is the absolute value of the discretionary abnormal accruals, calculated using the modified Jones model, adjusted for ROA. The results show a significant negative coefficient for Optout, suggesting that firms that opt out of the accounting rules exemption have lower absolute abnormal accruals; thus, H2a is supported.

Table 5. Opting Out of Accounting Rules Exemption and Earnings Management

\begin{tabular}{lccl}
\hline \multirow{2}{*}{ Variable } & DV $=A b s D a$ & \\
\cline { 2 - 4 } & Estimate & $t$-value & $p$-value \\
\hline Intercept & 0.9887 & 3.67 & 0.000 \\
Optout & $\mathbf{- 0 . 4 9 7 6}$ & $\mathbf{- 2 . 0 5}$ & $\mathbf{0 . 0 4 1}$ \\
Sml_Rpt & $\mathbf{0 . 5 5 8 4}$ & $\mathbf{2 . 0 1}$ & $\mathbf{0 . 0 4 4}$ \\
Big4 & $\mathbf{- 0 . 9 1 0 1}$ & $\mathbf{- 3 . 0 8}$ & $\mathbf{0 . 0 0 2}$ \\
Lev & -0.0025 & -0.54 & 0.590 \\
Loss & 0.1926 & 1.58 & 0.115 \\
Cf & $\mathbf{- 0 . 0 1 9 3}$ & $\mathbf{- 2 . 6 9}$ & $\mathbf{0 . 0 0 7}$ \\
Growth & 0.0000 & -1.00 & 0.318 \\
Industry effects & Yes & & \\
Year effects & Yes & & \\
$N$ & 1426 & & \\
Adj. $R^{2}$ & 0.068 & & \\
\hline
\end{tabular}

Table 5 presents the coefficient estimates from OLS regression using the modified Jones model, adjusted for ROA, to estimate abnormal accruals for firms choosing to opt out of Section 107 of the JOBS Act. Amounts shown in bold are significant at least at the 5 percent level. Fixed effects are included for year and industry. All variables are defined in Appendix A. 


\subsection{EGC Decision to Opt Out and Restatement of Financial Statements}

Table 6 presents the results for the testing of H2b, which states that EGCs that chose to opt out of the accounting standards exemption are less likely to restate their financial statements. The dependent variable, Restatement, is an indicator variable equal to 1 if an EGC restates their financial statements, and 0 otherwise. We present results from both logistic and OLS regression analyses. As shown, the Optout variable is negative and significant in both models, suggesting that EGCs that choose to opt out of the accounting standards exemption are less likely to restate their financial statements. The untabulated odds ratio estimate from logistic regression analysis suggests that firms that opt out of accounting rules exemptions are $38 \%$ less likely to restate their financial statements as compared to firms that do not opt out of accounting rules exemption; thus, $\mathrm{H} 2 \mathrm{~b}$ is supported.

Table 6. Opting Out of Accounting Rules Exemption and Financial Statement Restatement

\begin{tabular}{|c|c|c|c|c|c|c|}
\hline \multirow[b]{2}{*}{ Variable } & \multicolumn{3}{|c|}{ Logistic Regression Analysis } & \multicolumn{3}{|c|}{ OLS Regression Analysis } \\
\hline & Estimate & $t$-value & $p$-value & Estimate & $t$-value & $p$-value \\
\hline Intercept & -1.8543 & -6.26 & $<.0001$ & 0.1219 & 5.22 & $<.0001$ \\
\hline Optout & -0.4809 & -2.01 & 0.045 & -0.0331 & -1.89 & 0.058 \\
\hline Sml_Rpt & -0.3465 & -1.22 & 0.225 & -0.0239 & -1.22 & 0.223 \\
\hline Big4 & -0.4874 & -1.79 & 0.073 & -0.0319 & -1.71 & 0.088 \\
\hline Lev & 0.0024 & 0.36 & 0.720 & 0.0002 & 0.37 & 0.712 \\
\hline Loss & -0.0895 & -0.32 & 0.749 & -0.0055 & -0.30 & 0.763 \\
\hline$C f$ & 0.0036 & 0.75 & 0.456 & 0.0002 & 1.33 & 0.184 \\
\hline Growth & 0.0000 & 1.25 & 0.213 & 0.0000 & 0.62 & 0.533 \\
\hline Industry effects & Yes & & & Yes & & \\
\hline Year effects & Yes & & & Yes & & \\
\hline$N$ & 1436 & & & 1436 & & \\
\hline Pseudo $R^{2}$ & 0.283 & & & & & \\
\hline Adj. $R^{2}$ & & & & 0.156 & & \\
\hline
\end{tabular}

Table 6 presents the coefficient estimates from Logistic and OLS regression of Opting Out of Section 107 of the JOBS Act (i.e., firms choosing to forego the election to delay the adoption of new or revised accounting standards) and financial statement restatements. Amounts shown in bold are significant at least at the 5 percent level. Fixed effects are included for year and industry. All variables are defined in Appendix A.

\section{Discussion}

Most prior studies on EGCs and the JOBS Act have concentrated on the overall costs and benefits of allowing EGCs reduced reporting requirements. This study examines a more specific form of exemption available to EGCs' choice to opt in or out of adopting future new or revised accounting standards. The empirical findings suggest that smaller firms, likely with less access to capital, are more likely to delay the adoption of new or revised accounting standards due to concerns about the costs associated with compliance. Due to the extended transition period afforded to these firms, they can determine the most efficient and cost-effective way to comply with new or revised accounting standards once their EGC designation expires. Based on these findings, it appears as though the objective of the JOBS Act, to reduce costs associated with and ease access to external capital, has been successful for those EGC firms that are also designated as an SRC.

The results also suggest that EGCs that employ Big 4 auditors are more likely to opt out of the extended transition period and comply with new or revised accounting standards as if they were a non-EGC firm. We find that those EGCs able to afford the services of Big 4 auditors are likely to have access to greater resources and are less likely to be categorized as an SRC. Due to their access to resources, retaining a Big 4 auditor likely allows these EGCs to meet the challenges associated with complying with new or revised accounting standards. In addition, the results suggest that auditor choice plays an important role in the decision to opt in or out of Section 107 of the JOBS Act.

We find that EGC firms that choose to opt out are less likely to engage in accruals-based earnings management and are less likely to restate their financial statements. Taken together, the findings suggest EGCs that chose to opt out of 
Section 107 of the JOBS Act produce higher quality financial statements than do those that chose to opt in. These findings shed light on the reporting quality of EGC firms and show that an association exists between the decision to opt in or out of Section 107 of the JOBS Act and financial reporting quality. These findings as well as our earlier findings that EGCs that chose to opt out are more likely to have BIG 4 auditors, indirectly support a long line of literature that suggests that clients of Big 4 firms are associated with higher quality earnings.

This study contributes to the debate on the costs and benefits of regulatory exemptions allowed for firms as they relate to accounting standards. Our empirical study shows that allowing firms to choose accounting rules exemptions may result in lower quality financial statements, which may have adverse effects on investment decisions. Based on our findings, we contend that regulators should be cautious when allowing reporting exemptions that may affect financial reporting quality. Our findings may be helpful in initiating a conversation about designing a phase-in strategy or implementation guidelines for firms that are unable to meet the challenges associated with the issuance of new or revised accounting standards.

\section{Summary, Conclusion, and Limitations of the Study}

In this study, we hand collected data on EGC firms to investigate the types of firms that would choose to adopt the new or revised accounting standards rather than delay the adoption afforded them through Section 107. We then employ various analyses, using logistic and OLS regressions, to examine the determinants and consequences of choosing to adopt new accounting standards voluntarily. In doing so, we control for various other explanatory variables. Tests of $\mathrm{H} 1 \mathrm{a}$ and $\mathrm{H} 1 \mathrm{~b}$ show that firms that are considered SRCs and firms that employ non-Big 4 auditors are likely to forego adoption of new accounting standards as allowed by the JOBS Act. These results suggests that SRCs and firms that employ non-Big 4 auditors view adoption of new accounting standards as costly. Potentially, the benefits perceived by these firms that stem from the adoption of new accounting standards is lower than the costs of such adoption. These findings allow us to answer the question, "What type of firms choose to opt in versus opt out of Section 107 of the JOBS Act?"

We also examined the potential consequences of foregoing adoption of new accounting standards as it relates to a firm's earnings quality. In doing so, we proxy earnings quality, using abnormal accruals quality and financial restatement indicators. These proxies have been used extensively in prior literature for empirical evidence of financial statement quality. In our study, both proxies provide consistent result, as firms that choose to adopt new accounting standards commit to producing higher quality financial reports. These findings allowed us to answer the question, "Does the decision to opt in or opt out of Section 107 of the Jobs Act influence firm financial reporting quality and restatement behavior?"

To the best of our knowledge, we are the first to empirically investigate and document the various determinants and consequences associated with an EGC's choice to opt in or out of Section 107 of the JOBS Act. Our findings should be of interest to regulators in their examination of the impact that the JOBS Act has had on access to external capital for EGCs. In addition, the findings should be of interest to investors and analysts in their determination of EGC investment risk. Finally, our findings should be of interest to researchers who seek to examine the association between EGCs and various attributes related to capital markets. Our findings, coupled with prior research on the association between the JOBS Act and the IPO market, shed light on the role that EGC firm characteristics play in IPO mispricing and information asymmetry.

We conclude by acknowledging the limitations of this study and by suggesting avenues for future research. As with most empirical studies, there are some limitations worth noting. First, we are unable to collect data for all EGC firms sampled during the period, either due to an inability to determine their decision to opt in or out of Section 107 or due to a lack of financial data required to perform empirical analysis. As such, we cannot rule out the possibility that the determinants and consequences noted could be significantly different had we been able to collect data on the full sample. Second, we use abnormal accruals and financial statement restatement as proxies for earnings quality. Abnormal accruals and financial statement restatements, however, cannot fully capture the underlying quality of a firm's reported earnings. Future research could further explore the association between EGC firm characteristics and alternative measures of earnings management, quality, and informativeness and IPO mispricing.

\section{Acknowledgments}

We would like to thank the editor and reviewers for their helpful insight on developing our study.

\section{References}

Balsam, S., Krishnan, J., \& Yang, J. S. (2003). Auditor industry specialization and earnings quality. Auditing: A Journal of Practice and Theory, 22(2), 71-97. http://doi.org/10.2308/aud.2003.22.2.71 
Barth, M. E., Landsman, W. R., \& Taylor, D. J. (2017). The JOBS Act and information uncertainty in IPO firms. The Accounting Review, 92(6), 25-47. http://doi.org/10.2308/accr-51721

Bilal, N., Chen, S., \& Komal, B. (2018). Audit committee financial expertise and earnings quality: A meta-analysis. Journal of Business Research, 84, 253-270. https://doi.org/10.1016/j.jbusres.2017.11.048

Chaplinsky, S., Hanley, K. W., \& Moon, S. K. (2017). The JOBS Act and costs of going public. Journal of Accounting Research, 55(4), 795-836. https://doi.org/10.1111/1475-679X.12172

Dambra, M., Field, L. C., \& Gustafson, M. (2015). The JOBS Act and IPO volume: Evidence that disclosure costs affect the IPO decision. Journal of Financial Economics, 116(1), 121-143. https://doi.org/10.1016/j.jfineco.2014.11.012

Dambra, M., Field, L. C., Gustafson, M., \& Pisciotta, K. J. (2016). Pre-IPO communications and analyst research: Evidence surrounding the JOBS Act (Working paper, Buffalo State College, SUNY, University of Delaware and The Pennsylvania State University). $\quad$ Retrieved from http://www.fmaconferences.org/Vegas/Papers/Pre_IPO_Communications_FMA2016.pdf.

Francis, J., \& Krishnan, J. (1999). Accounting accruals and auditor reporting quality conservatism. Contemporary Accounting Research, 16(1), 135-165. https://doi.org/10.1111/j.1911-3846.1999.tb00577.x

Gipper, B. (2016.) Assessing the effects of disclosing management compensation (Working paper, The University of Chicago Booth School of $\quad$ Business). $\quad$ Retrieved from https://www.gsb.stanford.edu/sites/gsb/files/brandongipperjmp2016.pdf

Guasch, M. 2017. The information content of earnings announcements in newly public firms: Evidence from the JOBS Act (Working Paper, Universitat Pompeu Fabra). Retrieved from https://pdfs.semanticscholar.org/c5ed/b67e194bc0a683ca3e6a80d58f30e69b3167.pdf.

Jensen, M. R. H., Marshall, B. B., \& Jahera, J. S. (2012). Global trends: U.S. IPO market declines. Journal of Corporate Accounting \& Finance, 23(6), 17-28. https://doi.org/10.1002/jcaf.21795

Jumpstart Our Business Startups Act. (2012). House Resolution 3606. 112th Congress (United States). Retrieved from https://www.congress.gov/bill/112th-congress/house-bill/3606

Kim, J. B., Chung, R., \& Firth, M. (2003). Auditor conservatism, asymmetric monitoring, and earnings management. Contemporary Accounting Research, 20(2), 323-259. https://doi.org/10.1506/J29K-MRUA-0APP-YJ6V

Kothari, S. P., Leone, A. J., \& Wasley, C. E. (2005). Performance matched abnormal accrual measures. Journal of Accounting and Economics, 39(1), 163-197. https://doi.org/10.1016/j.jacceco.2004.11.002

Loyeung A., \& Matolcsy, Z. (2016). The cost of implementing new accounting standards: The case of IFRS adoption in Australia. Australian Journal of Management, 41(4), 611-632. doi:10.1177/0312896216649015

Ritter, J. R., \& Welch, I. (2002). A review of IPO activity, pricing, and allocations. The Journal of Finance, 57(4), 1795-1828. https://doi.org/10.1111/1540-6261.00478

Teoh, S., \& Wong, T. (1993). Perceived auditor quality and the earnings response coefficient. Accounting Review, 68(2), 346-366. https://www-jstor-org.unr.idm.oclc.org/stable/248405

Westfall, T., \& Omer, T. 2(018). The emerging growth company status on IPO: Auditor effort, valuation and underpricing. Journal of Accounting and Public Policy, 37(4), 315-334. https://doi.org/10.1016/j.jaccpubpol.2018.07.003

Zimmerman, A. B. (2015). The JOBS Act disclosure exemptions: Some early evidence. Research in Accounting Regulation, 27, 73-82. https://doi.org/10.1111/1540-6261.00478 


\section{Appendix A: Variables and Measures}

\begin{tabular}{ll}
\hline Variable & Measure \\
\hline Optout & Indicator variable equal to 1 if EGC firms opt out of the accounting rules exemption, and 0 otherwise \\
Sml_Rpt & Indicator variable equal to 1 if EGC firms list themselves as an SRC in SEC filings, and 0 otherwise \\
Big4 & Indicator variable equal to 1 if EGC firms employ one of the Big4 auditors, and 0 otherwise \\
Lev & Firm's leverage calculated as total debt divided by book value of equity \\
Loss & Indicator variable equal to 1 if firms report loss from operation at the end of the fiscal year, and 0 \\
& otherwise \\
Cf & Firm's cash flow from operations scaled by total assets at year end \\
Growth & Firm's market value of equity divided by book value of equity at year end \\
AbsDa & Absolute value of abnormal accruals calculated following the modified Jones model adjusted for \\
& financial performance, following Kothari et al. (2005) \\
Restatement & Indicator variable equal to 1 if firm restates its financial statement, and 0 otherwise
\end{tabular}

\section{Notes}

Note 1. Section 107(b) Special Rule states: Notwithstanding subsection (a), with respect to the extension of time to comply with new or revised accounting standards provided under section 7(a)(2)(B) of the Securities Act of 1933 and section 13(a) of the Securities Exchange Act of 1934, as added by section 102(b), if an emerging growth company chooses to comply with such standards to the same extent that a non-emerging growth company is required to comply with such standards, the emerging growth company: (1) must make such choice at the time the company is first required to file a registration statement, periodic report, or other report with the Commission; (2) may not select some standards to comply with in such a manner and not others, but must comply with all such standards to the same extent that a non-emerging growth company is required to comply with such standards; and (3) must continue to comply with such standards to the same extent that a non-emerging growth company is required to comply with such standards for as long as the company remains an emerging growth company.

Note 2. Hereafter, we refer to the option to delay adoption of the new or revised accounting standards as the "accounting standards exemption."

Note 3. Prior to September 10, 2018, SRCs are defined as those firms with a public float of less than $\$ 75$ million or less than \$50 million of annual revenues and no public float. Effective September 10, 2018, SRCs are those firms with a public float of less than $\$ 250$ million or less than $\$ 100$ million of annual revenue and (i) no public float or (ii) a public float of less than $\$ 700$ million. For the purposes of this study, we consider smaller reporting companies as those in accordance with the pre-September 10, 2018, requirements.

Note 4. Companies that offered IPOs prior to December 8, 2011, are not eligible to be EGCs.

Note 5. Mandatory disclosures for companies outside of the JOBS Act are governed by the Securities Acts of 1933 and 1934.

Note 6. All JOBS Act provisions, except crowdfunding, are available to foreign companies.

Note 7. A large accelerated filer is a company that has been public for at least 12 months, has filed one form 10-K, and has a public float of at least $\$ 700$ million. 